\section{Japan barely joins SDI goldrush \\ Tokyo}

JAPANESE companies have just won their first - and perhaps last - contracts from the US Strategic Defense Initiative (SDI).

Japan was slow to get involved in SDI and the programme may fade away before Japan has a chance to enter the SDI league table (see below). The two new contracts were awarded to Japanese consortia by the US Department of Defense for the design of a defense system to protect Japan and the west Pacific from Soviet missile attack. The one-year contracts, worth $\$ 3$ million each, will be shared by 18 US and Japanese companies. Mitsubishi Heavy Industries, a major Japanese defence contractor, leads one group of thirteen companies and LTV Corporation, a US steel maker, heads the other.

The Japanese electronics giants NEC, Fujitsu, Hitachi and Mitsubishi Electric are among the participants.

Japan trails far behind Israel and Western European countries which have

\section{SDI contract dollars}

Israel

$\$$ million

West Germany

161.93

United Kingdom

63.21

44.19

12.07

9.41

Italy

6.25

1.07

France

0.09

Belgium

The value of contracts let under the auspices of the US Strategic Defense Initiative Office (SDIO). The total for the Netherlands includes $\$ 7$ million from the government of the Netherlands, and the Israeli government contributed $\$ 31.6$ million to its SDI contracts. There are 122 contracts with foreign countries for participation in SDI. Data provided by the SDIO, complete to end October 1988.

J.P.

won large SDI contracts. Negotiations over Japan's participation, which began nearly four years ago, proceeded slowly, partly because Japanese companies have no experience in taking out contracts with the Pentagon and partly because special measures had to be introduced in Japan to protect "military secrets". In April, Japan and the United States agreed to a system for filing classified patents in Japan. Before that all patents were made public.

Japan may now never win substantial SDI contracts, given the chances the programme will be scaled down in a new US administration. But SDI has opened the way for increased collaboration between the US and Japan in the development of military technology.

David Swinbanks

\title{
Thalidomide scientist "guilty of fraud" says committee
}

\section{Sydney}

William McBride, the Australian medical researcher credited with discovering that the drug thalidomide could cause birth defects, has been found guilty of scientific fraud in his research into another morningsickness drug. McBride has resigned from Foundation 41 , the institute he founded and directed.

Allegations that McBride had fabricated and altered data published in the Australian Journal of Biological Sciences were first made in December 1987 by Norman Swan, the Australian Broadcasting Corporation's health correspondent. McBride's paper stated that orally administered hyoscine, an anticholinergic drug, causes birth defects in rabbits. Swan claimed the real results had been inconclusive, with only one of six rabbits giving birth to a deformed litter. He said McBride had changed the results to show that more deformed rabbits were born and published the paper without the knowledge of his junior researchers.

An early draft of the paper appeared as evidence in a US lawsuit in 1981 in which it was alleged that the drug Bendectin (also known as Debendox) contained an anticholinergic agent and was thus potentially dangerous. The drug was withdrawn from the market in 1983.

Public pressure resulting from Swan's allegations forced Foundation 41 to begin an inquiry earlier this year. As the foundation is an independent organization, it turned to an outside committee chaired by Sir Harry Gibbs, a former Chief Justice,
Roger Short, professor of anatomy at Monash University, and Robert Porter, director of the John Curtin School of Medicine.

In a statement released by Foundation 41 last week. the committee said that McBride had "deliberately falsified" the disputed article. "The experiment mentioned in the paper was not conducted in accordance with proper scientific method and was not honestly reported. . . we are forced to conclude that Dr McBride did publish statements which he either knew were untrue or which he did not genuinely believe to be true, and in that respect was guilty of scientific fraud".

McBride disputes the verdict. In an interview broadcast on Sydney's Channel 7 news, he said that "by the way the committee concluded its affairs I was denied natural justice . . . the terms of reference [of the inquiry] were very narrow. I deny the findings of the committee. I had nothing to gain by falsifying data. I am not guilty of scientific fraud."

McBride may now be investigated under the Medical Practitioners' Act of 1987. Although the act deals with medical rather than scientific improprieties, Merrilyn Walten of the State Health Department's complaints unit says that McBride could face deregistration as a medical practitioner on the grounds of not being "a fit and proper person to practise medicine". A recommendation on further action will be presented to the medical tribunal within the next three weeks.

Tania Ewing

\section{Ethical issues in vogue at MIT}

\section{Boston}

THE growing interest in issues of ethics in science and technology was underlined by a standing-room-only crowd of 850 students, faculty and staff from the Massachusetts Institute of Technology (MIT) at a university-wide colloquium last month entitled "How to be Good". Following the formal presentations, dozens of workshops continued to discuss the issues raised well into the night.

Charles Whetsel, an undergraduate senior at MIT, and one of the organizers of the event, says that the ethics colloquium was intended to "get the ball rolling" on a subject that is "very much in the forefront of people's minds". Although no official proposals have yet been offered, many faculty and administrators are debating the issue of how better to integrate ethical issues into the school's curriculum.

Sheila A. Widnall, professor of aeronautics and astronautics and past president of the American Association for the Advancement of Science, argued that courses on ethics and increased insertion of ethical issues into regular course curricula are needed to raise student awareness of ethical issues. Faculty members at MIT, she said, have "a responsibility to set an academic climate where one is not pressured into dishonesty to maintain one's academic standing". Philip Morrison, emeritus professor of physics, spoke about two key decisions he had made in his career that required him to reconsider his own values. He contrasted his decision to participate in the creation of the atomic bomb in the Second World War with his decision to not to work for the Rand Corporation. The one, he said, was an effort to thwart "the extension of fascism throughout the whole world", while the other would have meant studying "waging of intercontinental warfare by any and all means".

Seth Shulman 